\title{
Maladaptive Personality Traits, Religiosity and Spirituality as Predictors of Epistemically Unfounded Beliefs
}

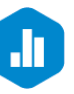

Peter Teličák (D), Peter Halama

Institute of Experimental Psychology, Centre for Social and Psychological Sciences, Slovak Academy of Sciences, Bratislava, Slovak Republic

The present research focuses on the question whether spirituality, religiosity and maladaptive personality traits, as measured by the PID-5 (antagonism, psychoticism, disinhibition, negative affectivity, detachment), predict epistemologically unfounded beliefs (conspiracies, pseudo-science and paranormal beliefs). The sample included 829 participants recruited through social networks ( $58 \%$ women, mean age 29.98 years). The results showed that especially psychoticism is a positive predictor of all types epistemologically unfounded beliefs (EUB). Spirituality and religiosity predicted only paranormal beliefs with very small effect size. No interaction between psychoticism and spirituality/religiosity in prediction of EUB was found. Results confirmed that some maladaptive personality traits (especially psychoticism) can play a significant role in EUB and should be taken into account when considering sources of EUB at the individual level.

Key words: maladaptive personality traits, PID-5, epistemically unfounded beliefs, religiosity, spirituality

\section{Introduction}

According to Lobato et al. (2014), epistemologically unfounded beliefs (EUB) are the type of beliefs which are not in accordance with the totality of knowledge and evidence of contemporary science. Their accuracy cannot be verified and they may even be in conflict with current knowledge. Lobato et al. (2014) suggested three types of such beliefs: con- spiracies (e.g., the fall of the twin towers in the US caused by the US government), pseudo-scientific beliefs (e.g., refusal to vaccinate), and paranormal beliefs (e.g., belief in the existence of ghosts). Conspiracy beliefs involve the existence of various factors operating in secrecy to achieve, hidden illegal or even malicious objectives (van Prooijen \& Acker, 2015). We can define them as unverified and relatively unsustainable claims (Brotherton \& French, 2014). Pseudoscientific beliefs do not

Correspondence concerning this article should be addressed to Peter Teličák, Institute of Experimental Psychology, Centre for Social and Psychological Sciences, Slovak Academy of Sciences, Dúbravská cesta 9, 84104 Bratislava, Slovak Republic. E-mail: peter.telicak@savba.sk Research data for this article is available at https://journals.savba.sk/index.php/studiapsychologica/article/view/208

Received August 17, 2020

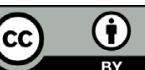


have hypotheses that can be tested (Wood et al., 2012), they have a dubious methodology, they often base the evidence on "authority" and not on evidence, and last but not least, they do not revise the claims (Gauch, 2012). They are inconsistent with the totality of knowledge and evidence of contemporary science (Lobato et al., 2014) and their rationale can often be bullshit (Pennycook et al., 2016; Čavojová et al., 2019). Paranormal beliefs represent a multidimensional construct (Lindemana \& Aarnio, 2007) that incorporates a belief in magical phenomena and superstitions. This type of belief is subject to belief in physical, biological, or psychological phenomena that go beyond scientific laws and have a metaphysical character (Lindeman \& Aarnio, 2007). An interesting feature of the EUB is that, although they may contradict each other in content and meaning, they are related to each other (Wood et al., 2012). For example, submission to conspiracy theories predicts submission to paranormal or pseudoscientific beliefs (Newheiser et al., 2011; Lobato et al., 2014). Thus, other various unsubstantiated beliefs appear to be a strong predictor of belief in unfounded beliefs (Swami et al., 2010; Swami et al., 2011).

The main psychological function of these beliefs is to provide broad and internally consistent explanations that allow the world to be perceived as organized (Lantian et al., 2017), and contribute to a sense of meaning and control (van Prooijen \& Jostmann, 2013). From an evolutionary point of view, EUBs are considered either a by-product of the evolution of psychological mechanisms (such as pattern recognition, detection of hazards and opportunities) or a part of an evolved adaptive psychological mechanism (van Prooijen \& van Vugt, 2018). Examining these beliefs is important as they have a negative impact in many areas such as intergroup dynamics (Graeupner \& Coman, 2017) or health (Jolley \& Douglas, 2017), and they can lead to prejudice, discrimination, aggression (Jolley et al., 2019), and political extremism (van Prooijen et al., 2015).

Many sources of EUB have been studied in recent years including social (Graeupner \& Coman, 2017), personality (Lobato et al., 2014) or cognitive ones (Ståhl \& Van Prooijen, 2018). In the current study, we focused on the relationship between maladaptive personality variables and EUB. Until now, most of the personality research on EUB has been done from the Big Five perspective. Lobato et al. (2014) found that extraversion and neuroticism are predictors of EUB. Other studies found weak but significant relationships between various conspiracy beliefs and higher levels of openness and lower levels of agreeableness (Swami et al., 2010; Swami \& Furnham, 2012). However, recent metanalysis (Goreis \& Voracek, 2019) of the relationship between Big Five personality traits and conspiracy beliefs showed that none of these personality traits is significantly associated with conspiracy beliefs. Psychopathological personality variables seems to be more promising when studying EUB. Darwin et al. (2011) demonstrated that EUB beliefs are related to schizotypal personality traits and paranoidity, a finding also confirmed by Barron et al. (2014). Schizotypy, which is defined as a set of personality traits that are associated with increased susceptibility to schizophrenia (Kwapil \& Barrantes-Vidal, 2015), includes strange and bizarre behavior, strange speech, magical thinking, unusual sensory experiences, and a reduced interest in interpersonal relationships (Chylová et al., 2017). Paranoidity includes suspiciousness and touchiness and can lead to a distorted perception of reality (Van Elk, 2015). Darwin et al. (2011) suggested that conspiracy beliefs in particular may provide some adaptive benefit to persons with paranoid and schizotypical traits through which they release their negative intentions. 
Pathological personality traits are represented by an Alternative Model of Personality Disorders (PID-5). Although this model is not an official part of the DSM-5 diagnostics, it is included in Section III, a section describing emerging measures and models of psychological disorders (APA, 2013). The model includes five dimensions, each of them maladaptive extremes of one of the Big Five personality traits, and therefore it is frequently understood as a pathological extension of the five-factor model of personality (Suzuki et al., 2015). APA (2013) characterizes these traits as follows: Negative affectivity is the opposite of emotional stability manifested by strong and frequent feelings of anxiety, depression, guilt, and anger. Detachment can be seen as the opposite of extraversion, which leads to the avoidance of interpersonal relationships. Perception and expression of emotions are limited. Antagonism is the opposite of agreeableness and is described by feelings of self-importance. One is not aware of the needs and feelings of other people, tends to be ruthless, or is ready to use others for one's purposes. Disinhibition is the opposite of conscientiousness. High rates of disinhibition are characterized by impulsive behavior aimed at immediately satisfying one's own needs. This way of acting is based on current thoughts and feelings from external stimuli, regardless of experience and possible future consequences. Psychoticism is the extreme maladaptive extension of Openess. This part of psychopathological variables includes a wide variety of behaviors and thinking that are incompatible with the socio-cultural context. It can often be considered eccentric, unusual, or even weird.

In this model the pathological traits are usually measured by Personality Inventory for the DSM-5 (PID-5, Krueger et al., 2012). The research using this measure showed that especially negative affectivity and psychoticism has been linked to EUB. Psychoticism was found to be a correlate of paranormal beliefs (Cella et al., 2012; Hinterbuchinger et al., 2018) and suspicion (dimension of negative affectivity) and unusual forms of beliefs and experiences (dimension of psychoticism) were linked to conspiracy beliefs (Swami et al., 2016). Genovese (2005) pointed to the relationship between paranormal beliefs and a disorganized form of schizotypal thinking (various esoteric tendencies). These dissociative tendencies are related to anxiety (Muris et al., 2003), which, along with depression predict superstition (Dudley, 2000). Research suggests that people experiencing anxiety or helplessness have higher probability to believe in unfounded beliefs (Abalakina-Paap et al., 1999; Grzesiak-Feldman, 2013; van Prooijen, 2018).

Along with psychopathological traits, we also included religiosity and spirituality $(R / S)$ in our study. Religiosity and spirituality are distinct but related variables, frequently researched together. Miller (2012) considers spirituality and religiosity to be parallel in scope, noting that religiosity is a public aspect of experiencing spirituality. Religiosity and spirituality provide an integrated set of beliefs, goals, and meanings related to supernatural or transcendental reality, which help cope with personal adversities and problems (Aldwin et al., 2014; Park, 2013, 2017). Previous research suggested that religious variables had slightly negative reliationship with traits included in PID-5, especially with detachment, antagonism and dishinbition (Suzuki, Griffin, \& Samuel, 2017). This is in line with previous research on the relationship of mental health with religious and spiritual variables (Hackney \& Sanders, 2003; Hodapp \& Zwingmann, 2019). On the other hand, connection of religiosity and spirituality to EUB were found to be ambigious. Van Prooijen \& Douglas, (2018) assume that more individuals who are strongly religious are subject to the 
EUB. Religiosity was found to be positively related to paranormal beliefs (Darwin et al., 2011; Rice, 2003; Halama, 2019b), which can be explained by the fact that religiosity and paranormal beliefs build upon the belief in phenomena that cannot be subjected to scientific research (Huntley et al., 2005; Rice, 2003). Pennycook et al. (2012) examined the interrelationship between analytical cognitive style and religious and paranormal beliefs. The results showed that the cognitive analytical style is a negative predictor of both types of beliefs. However, some other research suggested that the relationship between $\mathrm{R} / \mathrm{S}$ and paranormal beliefs was negative (Beck \& Miller, 2001; Hergovich et al., 2005). Concerning conspiracy, previous results showed ambigious results as well. Some studies found positive relationship between religiosity and conspiracies (e.g., Mancosu, Vassallo, \& Vezzoni, 2017), while others did not (e.g., Jasinskaja-Lahti \& Jetten, 2019). These inconsistencies can sometimes be attributed to social and cultural factors related to the use of religious or spiritual symbols and proclamations by political ideological groups, which can be present in some countries. In the Slovak context, spiritual and religious contents has been present in right-wing political movements throughout the history (Drábik, 2017; 2019). These movements frequently lean on ideologies based on EUB (antivaccination, conspiracies related to government or minorities), which can result in a positive relationship betweeen reliogiosity/spirituality and EUB. On the other hand, official churches in Slovakia publicly reject conspiracies and pseudoscientific practices, which makes assumptions about possible relations between religiosity/ spirituality and EUB unclear. We can assume that religiosity/spirituality is both a positive and negative mediator of the relationship between psychopathological traits and EUB.
Across the research results, gender, age and education also appear to be predictors of the EUB. Astin (1998) points out that women are more subject to medical pseudoscience. On the other hand, Johnson (2004) makes observations that point to the absence of gender differences in the acceptance of pseudoscientific beliefs, as confirmed by Swami et al. (2016). Women scored higher than men in paranormal beliefs (Darwin et al., 2011) and conspiracy beliefs (Swami et al., 2011). Results from the Slovak context confirm this only in pseudo-scientific and paranormal beliefs (Halama, 2019). In the context of efforts to reduce the negative consequences of ENP, education is an important protective factor against ENP compliance (van Prooijen, Krouwel, \& Pollet, 2015; Douglas et al., 2016). Gervais and Norenzayan (2012) conclude that higher levels of education are associated with distrust of paranormal beliefs. Research findings from Van Prooijen (2017) consider age to be one of the predictors of conspiracy beliefs. Sociological research in the American population offers findings that people under the age of 35 are more subject to conspiracy beliefs than the elderly (Stempel el al., 2007), as confirmed by research findings by Swami et al. $(2012,2016)$. The results of other studies have shown that younger individuals are more subject to pseudoscientific (Tsai et al., 2012) and paranormal beliefs (predicting the future) (Shein et al., 2014).

\section{Purpose of the Study}

In our paper, we focused on examining the relationship between demographic variables psychopathological traits, religiosity/spirituality and EUB in the Slovak population. Our research goal is to examine whether PID-5 factors predict the rate of EUB independently of basic demographic variables (gender, age, and education). We also look at the question 
whether religiosity and spirituality are predictors of EUB after controlling for demographic variables and psychopathological traits. As there is an unclear assumption whether in the Slovak context religiosity/spirituality increase or decrease the effect of psychopathological traits on EUB, we will also explore whether there is an interaction between those traits which predict EUB and religiosity/spirituality.

\section{Method}

\section{Sample}

The research sample consisted of 829 respondents ( $58 \%$ women) aged 18 to 83 years $(M=$ $29.98, S D=11.28)$. The mean age of men was $M=31.58, S D=11.34$ and women $M=28.83$, $S D=11.07$. The level of education of the participants was: Primary school 22 (2.7\%), high school 388 (46.8\%), university 367 (34.3\%) and postgraduate studies 52 (6.2\%). Data was collected in November 2018. Recruiting of participants was carried out via social networks. Respondents were informed about the purpose of the studies and they expressed their agreement to participate.

\section{Measures}

The Scale of Epistemologically Unfounded Beliefs (Halama, 2019b) contains 18 items with answers on a 5-point Likert-type scale from 1 to 5 , with 1 = strongly disagree, 5 = strongly agree. The scale is divided into three dimensions: conspiracy beliefs (example item: The pharmaceutical industry conceals the existence of an effective cancer drug due to the financial gain from chemotherapy), pseudoscientific beliefs (example item: Vaccination is more harmful to humans than it helps) and paranormal beliefs (example item: The existence of ghosts and spirits is not fiction, but a real basis). None of the items are reverse scored.
The Short Personality Questionnaire for DSM-5 (PID5-BF) personality (Krueger et al., 2012) in the Slovak version (Heretik ml., Mihálová, Hajdúk, 2018) was used to measure psychopathological variables. It contains 25 items with answers on a 4-point Likert-type scale from 0 to 3; $0=$ very false or often false, 3 = very true or often true. The questionnaire is divided into five dimensions: detachment (example item: I often feel like nothing I do really matters), antagonism (example item: I crave attention), psychoticism (example item: I often have thoughts that make sense to me but that other people say are strange), disinhibition (example item: I feel like I act totally on impulse) and negative affectivity (example item: I worry about almost everything). None of the items are reverse scored.

The Santa Clara Strength of Religious Faith Questionnaire's short form (Storch et al., 2004) contains 5 items. Respondents in this questionnaire express the degree of agreement and disagreement with the given statements through a scale from 1 to $4 ; 1=$ strongly disagree, 4 = strongly agree (example item: I enjoy being around others who share my faith). None of the items are reverse scored.

The Daily Spiritual Experience Scale's short form (Underwood, 2011) contains 6 items in the Slovak version (Čavojová et al., 2019). Respondents in this questionnaire express the degree of agreement and disagreement with the given statements on a scale from 1 to 6 ; 1 = never or almost never, $6=$ many times a day (example item: I feel deep inner peace or harmony). None of the items are reverse scored.

\section{Statistical Procedures}

We used the statistical software SPSS, JAMOVI, and R-Studio to process the research data. To assess the psychometric properties (reliability) of the scales and individual dimensions, 
we used ordinal alpha, which we obtained by calculation using the R-Studio language, the "user-friendly science" module. We used skewness and kurtosis (Tabachnick \& Fidell, 2007) as a reference framework for evaluating the normality of data distribution. The relationships between PID-5, religiosity, spirituality, and EUB were examined by means of linear regression analysis using the Enter method with an estimate of the bootstrapping coefficient $(N=5000)$. Gender, age, and education were included in the regression equation as predictors in the first step, psychopathological variables from PID-5 in the second step, and religiosity/spirituality in the third step. The incidence of multicolinearity of predictors was estimated using VIF coefficients (they were in the favorable range of 1.02-3.11). To investigate interactions between selected PID-5 traits and religiosity/ spirituality, we used a simple moderation analysis using linear regression models by SPSS module Process v3.2 (Hayes, 2013). In this analysis, EUB was defined as outcome variables, selected maladaptive traits as predictors and religiosity/spirituality as moderators. Interaction effect was estimated through interaction term of predictor and moderator.

\section{Results}

The descriptive analysis of the measured variables is presented in Table 1 . As seen, no variable exceeded the value 1.5 of kurtosis or skewness, which is considered a serious violation of normality (Tabachnick \& Fidell, 2007). Also, internal consistency of the measures was satisfactory across all measures. Table 2 shows the relationships between the measured variables. As seen, there are weak positive relationships between all dimensions of the EUB and spirituality and religion. Psychoticism and negative affectivity have weak positive relationships with all dimensions of the EUB. Dis- inhibition has positive weak relationships with conspiratorial and paranormal beliefs. The results of the regression analysis are shown in Table 3. Demographic variables (gender, age) are shown to be significant predictors of all types of EUBs, with the percentage of explained variance ranging from 8 to 10 for individual EUBs. In all cases, women and younger persons had greater chance to accept EUBs. Education proved to be a negative predictor of EUB, however, only for conspiracy and pseudo-scientific beliefs. In the second step of the regression analysis, it was shown that psychopathological variables (PID-5) significantly predict all EUBs beyond the prediction of demographic variables, mostly for paranormal beliefs $\left(\Delta R^{2}=0.05\right)$ and less for conspiracy beliefs $\left(\Delta \operatorname{Adj}^{2}=0.04\right)$ and pseudoscientific beliefs $\left(\Delta R^{2}=0.01\right)$. Concerning specific traits, psychoticism in particular has been shown to be a significant positive predictor of all EUBs. Detachment was found to be a negative predictor for conspiratorial and paranormal beliefs, however, the effect size was rather small. In the third step of the regression analysis, religiosity and spirituality was found to be significant predictors of paranormal beliefs $\left(\Delta R^{2}=0.07\right)$, and also of pseudoscientific beliefs, but this effect was quite small $\left(\Delta R^{2}=0.01\right)$.

In the last step, we carried out moderation analysis. As only psychoticism was a significant predictor of EUB with relevant effect size in regression analysis, we did moderation only for this maladaptive trait and only for conspiracies and paranormal beliefs (as pseudoscience was not significantly predicted by psychoticism). For conspiracy beliefs, the results showed that both religiosity and spirituality did not moderate the effect of psychoticism. The interaction effect was non-significant for religiosity $[\mathrm{B}=0.013 ; 95 \%$ C.I. $(-0.014$, $0.037), p=0.272]$ as well as for spirituality $[\mathrm{B}=0.135 ; 95 \%$ C.I. $(-0.001,0.028), p=0.066]$. 
Similar results were obtained for paranormal $\quad[B=0.015 ; 95 \%$ C.I. $(-0.009,0.039), p=$ beliefs as dependent variable. No significant 0.223 ] or spirituality $[\mathrm{B}=0.014 ; 95 \% \mathrm{C}$. . moderation effect was shown for religiosity $\quad(-0.001,0.029), p=0.056]$.

Table 1 Descriptive analysis of methods

\begin{tabular}{lccccccc}
\hline$N=829$ & $M$ & $M d$ & $S d$ & Ske & Kur & Ord $\alpha$ & items \\
\hline (EUB) Conspiracy & 13.66 & 13 & 5.88 & 0.45 & -0.61 & 0.88 & 6 \\
(EUB) Pseudoscience & 11.33 & 11 & 4.19 & 0.57 & 0.02 & 0.82 & 6 \\
(EUB) Paranormal & 14.73 & 14 & 6.24 & 0.40 & -0.71 & 0.82 & 6 \\
(PID) Detachment & 3.66 & 3 & 2.80 & 0.84 & 0.52 & 0.72 & 5 \\
(PID) Antagonism & 3.79 & 3 & 2.61 & 0.87 & 0.65 & 0.68 & 5 \\
(PID) Psychoticism & 5.03 & 5 & 3.31 & 0.57 & -0.05 & 0.80 & 5 \\
(PID) Disinhibition & 4.35 & 4 & 2.55 & 0.61 & 0.11 & 0.69 & 5 \\
(PID) Negative affectivity & 6.13 & 6 & 3.20 & 0.24 & -0.52 & 0.75 & 5 \\
Religiosity & 10.91 & 11 & 5.26 & 0.32 & -1.32 & 0.96 & 5 \\
Spirituality & 16.64 & 14 & 8.17 & 0.60 & -0.73 & 0.93 & 6 \\
\hline
\end{tabular}

Note. EUB - Epistemically unfounded beliefs, Ske - Skewness, Kur - Kurtosis

Table 2 Correlation matrix

\begin{tabular}{lcccccccccc}
\hline & Det & Ant & Psy & Dis & NA & Con & Pse & Par & Re & Sp \\
\hline Det & 1 & & & & & & & & & \\
Ant & $.20^{* *}$ & 1 & & & & & & & \\
Psy & $.36^{* *}$ & $.28^{* *}$ & 1 & & & & & & \\
Dis & $.21^{* *}$ & $.28^{* *}$ & $.37^{* *}$ & 1 & & & & & \\
NA & $.23^{* *}$ & $.16^{* *}$ & $.43^{* *}$ & $.30^{* *}$ & 1 & & & & \\
Con & -.02 & .04 & $.22^{* *}$ & $.07^{*}$ & $.19^{* *}$ & 1 & & & \\
Pse & -.01 & -.01 & $.14^{* *}$ & .06 & $.15^{* *}$ & $.76^{* *}$ & 1 & & \\
Par & -.02 & .04 & $.26^{* *}$ & $.12^{* *}$ & $.20^{* *}$ & $.62^{* *}$ & $.59^{* *}$ & 1 & & \\
Re & $-.08^{*}$ & -.06 & -.03 & $-.09^{*}$ & -.01 & $.07^{*}$ & $.09 *$ & $.24^{* *}$ & 1 & \\
Sp & $-.12^{* *}$ & -.05 & .07 & $-.07^{*}$ & -.05 & $.11^{* *}$ & $.12^{* *}$ & $.25^{* *}$ & $.81^{* *}$ & 1 \\
\hline
\end{tabular}

Note. Det - Detachment, Ant - Antagonism, Psy - Psychoticism, NA - Negative affectivity, Con - Conspiracy, Par - Paranormal, Pse - Pseudoscience, Re- Religiosity, Sp - Spirituality ${ }^{*} p<0.05,{ }^{* *} p<0.01$ 
Table 3 Results of regression analysis (standardized B)

\begin{tabular}{|c|c|c|c|c|}
\hline Model & Predictors & Con $B$ & Par $B$ & Pse $B$ \\
\hline \multirow[t]{4}{*}{1} & Gender & $.14^{* * *}$ & $.24 * * *$ & $.18 * * *$ \\
\hline & Age & $-.11^{* *}$ & $-.12 * *$ & $-.09 *$ \\
\hline & Education & $-.20 * * *$ & -.06 & $-.12 * *$ \\
\hline & $\mathrm{R}^{2}$ & $.10 * * *$ & $.09 * * *$ & $.08 * * *$ \\
\hline \multirow[t]{10}{*}{2} & Gender & $.13 * * *$ & $.23 * * *$ & $.17 * * *$ \\
\hline & Age & -.07 & $-.08 *$ & -.06 \\
\hline & Education & $-.18 * * *$ & -.03 & $-.10 * *$ \\
\hline & Detachment & $-.10 * *$ & $-.10 * *$ & -.05 \\
\hline & Antagonism & .03 & .02 & -.01 \\
\hline & Psychoticism & $.18^{* * *}$ & $.19 * * *$ & $.10^{*}$ \\
\hline & Disinhibition & -.02 & .06 & .00 \\
\hline & Negative affectivity & .07 & .05 & .05 \\
\hline & $\mathrm{R}^{2}$ & $.14^{* * *}$ & $.14^{* * *}$ & $.09 *$ \\
\hline & $\Delta \mathrm{R}^{2}$ & $.04^{* * *}$ & $.05 * * *$ & $.01 *$ \\
\hline \multirow[t]{12}{*}{3} & Gender & $.13^{* * *}$ & $.23 * * *$ & $.17^{* * *}$ \\
\hline & Age & -.07 & $-.08 *$ & -.07 \\
\hline & Education & $-.19 * * *$ & -.05 & $-.11 * *$ \\
\hline & Detachment & $-.08 *$ & -.07 & -.03 \\
\hline & Antagonism & .03 & .03 & .00 \\
\hline & Psychoticism & $.16^{* * *}$ & $.16^{* * *}$ & .08 \\
\hline & Disinhibition & -.02 & $.08 *$ & .01 \\
\hline & Negative affectivity & $.08^{*}$ & .06 & .06 \\
\hline & Religiosity & .02 & $.15^{* *}$ & .00 \\
\hline & Spirituality & .09 & $.12 *$ & $.12^{*}$ \\
\hline & $\mathrm{R}^{2}$ & $.15^{* *}$ & $.21 * * *$ & $.10^{* *}$ \\
\hline & $\Delta \mathrm{R}^{2}$ & $.01^{* *}$ & $.07 * * *$ & $.01 * *$ \\
\hline
\end{tabular}

Note. Gender (1 - male, 2 - female); Con - Conspiracy, Par - Paranormal, Pse - Pseudoscience ${ }^{*} p<0.05,{ }^{* *} p<0.01,{ }^{* * *} p<0.001$

\section{Discussion}

The purpose of the study was to examine whether maladaptive psychopathological variables, based on the PID-5 construct, together with religiosity and spirituality, predict epistemic unfounded beliefs (EUB), independently of basic demographic variables of gender, age, and education. The correlation analysis showed that psychoticism and negative affectivity were related to EUB, however, effect of 
negative affectivity was suppressed in later regression analysis. The results of the first step of the regression analysis showed that the EUB level is predicted by the observed demographic variables. Women, younger and less educated people have a higher preference for EUBs. Although the size of the regression coefficients implies a rather small effect (absolute values of regression coefficients range from 0.08 to 0.10 ), these results need to be taken into account. Education predicted negatively the level of conspiracy beliefs as well as pseudo-scientific beliefs and can be understood as a protective factor against these beliefs. Higher education reduces the inclination to conspiracy beliefs by increasing the feeling of control over the world and increasing cognitive complexity (Douglas et al., 2016; Van Prooijen, 2016, 2017). Education is also negatively related to the tendency to accept relatively simplistic explanations of more complex events (Rindermann \& Neubauer, 2004). Higher levels of education are associated with distrust of paranormal beliefs (Gervais \& Norenzayan, 2012), which, however, our research has not confirmed. We think that the possible explanation for this phenomenon may lie in the high level of religiosity in Slovakia, which means that highly educated persons can also accept paranormal beliefs related to religiosity, such as the existence of spirits or angels (Lindeman \& Aarnio, 2007).

In our sample, women scored higher in all EUB types. These results are in line with some previous studies (Lobato et al., 2014; Swami et al., 2011). Lobato et al. (2014) suggested that this could be explained by higher inclination of women towards intuitive cognitive process than men, which can lie behind the acceptance of EUB. However, Ballová Mikušková (2018) found that in Slovak students, there was no gender difference in different kinds of conspiracy beliefs, except that men scored higher in the so-called small groups conspiracies. This suggests that these differences do not have to be robust and there may be some specific EUBs for men and women. We can speculate that these specific EUBs can serve to different motivational/social preferences of men and women, however, more research support for this assumption is needed.

Our results suggested that younger persons had a higher inclination to EUB. Previous research produced contradictory results on this topic, in some cases higher age was related to EUB (e.g., Halama, 2019b; Van Prooijen, 2017), in other cases it was younger age (e.g., Swami et al., 2016). Taking into account very small effect sizes frequently found in such studies, we assume that the age effect on EUB can be more a function of specific sample characteristics in individual studies than a stable and robust phenomenon. One source of differences can be the sampling strategy, e.g. in our case online data collection through social networks. We can assume that older users of social networks can differ from the people of the same age with no access to social networks.

Concerning maladaptive traits, our results showed that psychoticism is an independent predictor of conspiracy and paranormal beliefs. Our findings support the results of previous studies, which found psychoticism to be a correlate of paranormal beliefs (Cella et al., 2012; Hinterbuchinger et al., 2018) and some features of psychoticism (unusual forms of beliefs and experiences) were related to conspiracy (Swami et al., 2016). The explanation for these effects can be attributed to characteristics of psychoticism, which is a maladaptive trait characterized especially by unusual forms of beliefs along with perceptual dysregulation (APA, 2013). Swami et al. (2016) suggested that individuals, who experience maladaptive cognitive-perceptual processing, may be more likely to accept a range of beliefs that are anomalous. This includes both 
conspiracy as well as paranormal beliefs. Persons with higher level of this maladaptive trait have an over-reliance on intuitive-experiential processing of information that is conducive to the acceptance of theories and ideas that lack evidence.

However, when discussing the effect of psychoticism, it is also important to mention, that psychoticism is sometimes considered psychometrically problematic (e.g., Crego et al., 2015) and its connection to openness is frequently questioned (Widiger \& Crego, 2019). Widiger and Crego (2019) emphasized that although psychoticism has been part of personality questionnaires for long years, it is still important to distinguish between psychoticism as a trait and psychoticism as cognitive delusions. Cognitive delusions have the nature of beliefs, which can be held consistently and they are not related to the trait of openness. If we accept this conceptualization of psychoticism, we can consider EUB as a part of persons' cognitive delusions.

In case of detachment, it was shown to be a negative predictor of conspiratorial and paranormal beliefs. Detachment is characterized by a lack of interest in the social environment and overall withdrawal along with anhedonia (APA, 2013). We think that detachment from social environment could protect against the exposure to EUB, because EUB is usually spread through social interaction (Franks, Bangerter, \& Bauer, 2013), which is limited in people with detachment. These results suggest that detachment could be a protective factor against EUB; however, we are hesitating to make conclusions about this connection. The beta coefficient of this effect was very small, and the results were not in line with previous research, which found no relationship between detachment and conspiracies (Swami et al., 2016). With such small effect sizes, the results can be accidental and should be verified in future research.
The results also showed that religiosity and spirituality added a specific effect not explained by demographic variables and maladaptive traits. However, this is valid only for paranormal belief, to which religiosity/spirituality add $7 \%$ of predicted variance. Our study confirmed the results of previous research, which also found a positive relationship between religiosity and paranormal beliefs (Darwin et al., 2011; Rice, 2003; Halama, 2019b). Paranormal beliefs are a multidimensional construct that incorporates magical, esoteric, superstitious, and even religious ways of thinking (Lindeman \& Aarnio, 2006; Cella et al., 2012; Hinterbuchinger et al., 2018). We consider these two areas (R/S vs. paranormal) as overlapping, because religious or spiritual worldview often includes paranormal beliefs. Pennycook et al. (2012) argue for the low level of analytic cognitive style as the common factor behind both kinds of beliefs, because analytic cognitive style was found to be a negative predictor of both types of beliefs. On the other hand, we did not find religiosity and spirituality predicting conspiracies and only a very small effect was found in case of pseudoscientific beliefs. Also, religiosity and spirituality did not work as moderator of the effect of psychoticism on EUB. This is in line with previous research, which brought inconsistent results on this topic (e.g., Jasinskaja-Lahti \& Jetten, 2019). As we argued above, we believe that this effect might be culturally dependent as it can be influenced by the degree to which conspiracy communities in different countries and regions use religious or spiritual symbols in their activities.

At the end, we need to comment on the narrow focus of our study. We dealt with only two sets of predictors (maladaptive traits and religiosity/spirituality), however, EUBs are multifactorial and they cannot be explained solely by the effects of pathological or personality tendencies. Also, the non-pathological social, 
identity and evolutional cognitive processes play a significant role in accepting EUBs (Bahna, 2015; Raab et al., 2013). The low effect sizes found in our study confirmed the assumption that EUBs are a complex multifactor phenomenon and a consequence of the interaction between personality, cognitive, social and other factors.

\section{Limitations}

The basic limitation of our study is its correlational nature. Although we tried to identify predictors of EUB and, theoretically, we considered maladaptive traits as causal factors of EUB, we did not apply a more advance methodological design, which would have been more appropriate for determining causality (e.g., longitudinal). However, along with other similar studies (e.g., Swami et al., 2016), we believe that even correlational studies can enlighten mutual relationships between maladaptive personality tendencies and EUB, and can bring important contribution to the knowledge in this area.

\section{Conclusions and Future Directions}

The results of a recent study (Globsec, 2020) showed that Slovaks believe in unfounded beliefs the most among the ten Central and Eastern European countries. It is therefore necessary to reflect upon possible variables, which contribute to accepting and spreading the EUBs. Our results confirmed that of the maladaptive traits, psychoticism is the one which can contribute to EUB, especially through the mechanism of maladaptive cognitive-perceptual processing. However, the effect of religiosity/spirituality on EUB was only weak and partial. Concerning future research, the effect of psychoticism and other maladaptive traits on EUB should be studied in interaction with other variables, especially existential variables such as the need for control over the world and life, etc. Previous research suggests that fear of death coming from human concerns about well-being and health, as well as negative social events may increase the tendency toward EUBs (Newheiser et al., 2011). Another promising area of EUB research is whether efect of psychoticism on EUB can be eliminated. Previous research (Jolley \& Douglas, 2017; Jolley et al., 2019) showed the general role of providing information in this process, however, there is a question, whether this effect is valid for people with higher psychoticism. The studies with experimental design can be useful in answering this questions, e.g. with interventions in groups with different level of maladaptive traits.

\section{Acknowledgement}

The study was supported by the Slovak Research and Development Agency as part of the research project APVV-16-0153: "Cognitive failures - individual predictors and intervention possibilities".

\section{Authors' ORCID}

Peter Teličák

https://orcid.org/0000-0001-8233-9769

Peter Halama

https://orcid.org/0000-0002-6938-4845

\section{References}

Abalakina-Paap, M., Stephan, W. G., Craig, T., \& Gregory, W. L. (1999). Beliefs in conspiracies. Political Psychology, 20(3), 637-647. https://doi. org/10.1111/0162-895X.00160

Aldwin, C. M., Park, C. L., Jeong, Y. J., \& Nath, R. (2014). Differing pathways between religiousness, spirituality, and health: A self-regulation perspective. Psychology of Religion and Spirituality, 6(1), 9-21. https://doi.org/10.1037/a0034416

American Psychiatric Association (APA). (2013). DSM-5 diagnostic classification. In Diagnostic and 
Statistical Manual of Mental Disorders (DSM-5 ${ }^{\circledR}$ ). American Psychiatric Pub.

Astin, J. A. (1998). Why patients use alternative medicine: Results of a national study. Journal of the American Medical Association, 279(19), 15481553. https://doi.org/10.1001/jama.279.19.1548

Bahna, V. (2015). Kognitívny a evolučný kontext šírenia konšpiračných teórií. Slovak Ethnology/ Slovenský Národopis, 63(3), 195-206.

Ballová Mikušková, E. (2018). Conspiracy beliefs in future teachers. Current Psychology, 37(3), 692701. https://doi.org/10.1007/s12144-017-9561-4

Barron, D., Morgan, K., Towell, T., Altemeyer, B., \& Swami, V. (2014). Associations between schizotypy and belief in conspiracist ideation. Personality and Individual Differences, 70, 156-159. https://doi.org/10.1016/i.paid.2014.06.040

Beck, R., \& Miller, J. P. (2001). Erosion of belief and disbelief: Effects of religiosity and negative affect on beliefs in the paranormal and supernatural. Journal of Social Psychology, 141(2), 277-287. https://doi.org/10.1080/00224540109600551

Brotherton, R., \& French, C. C. (2014). Belief in conspiracy theories and susceptibility to the conjunction fallacy. Applied Cognitive Psychology, 28(2), 238-248. https://doi.org/10.1002/ acp. 2995

Čavojová, V., Jurkovič, M., \& Brezina, I. (2019) To be or not to be bullshit? Obscuring the form vs. moving away from truthfulness. In Kognícia a umelý život (pp. 17-19). Bratislava: Univerzita Komenského.

Cella, M., Vellante, M., \& Preti, A. (2012). How psychotic-like are paranormal beliefs? Journal of Behavior Therapy and Experimental Psychiatry, 43(3), 897-900. https://doi.org/10.1016/i. jbtep.2012.01.003

Chylová, M., Marko, M., Dragašek, J., Virčík, M., Rovný, R., Roháriková, V., Murínová, J., Cimrová, B., Katina, S., \& Riečanský, I. (2017). Slovak adaptation of the Schizotypal Personality Questionnaire. Československá Psychologie, 61(3), 267-280.

Crego, C., Gore, W. L., Rojas, S. L., \& Widiger, T. A. (2015). The discriminant (and convergent) validity of the Personality Inventory for DSM-5. Personality Disorders: Theory, Research, and Treatment, 6(4), 321-335. https://doi.org/10.1037/ per0000118
Darwin, H., Neave, N., \& Holmes, J. (2011). Belief in conspiracy theories. The role of paranormal belief, paranoid ideation and schizotypy. Personality and Individual Differences, 50(8), 1289-1293. https://doi.org/10.1016/i.paid.2011.02.027

Drábik, J. (2017). Spreading the faith: The propaganda of the British Union of Fascists. Journal of Contemporary European Studies, 25(2), 211225. https://doi.org/10.1080/14782804.2016.1 219846

Drábik, J. (2019). Fašizmus. Bratislava: Premedia.

Dudley, R. T. (2000). The relationship between negative affect and paranormal belief. Personality and Individual Differences, 28(2), 315-321. https://doi.org/10.1016/S0191-8869(99)001002

Franks, B., Bangerter, A., \& Bauer, M. W. (2013). Conspiracy theories as quasi-religious mentality: An integrated account from cognitive science, social representations theory and frame theory. Frontiers in Psychology, 4, 424. https://doi. org/10.3389/fpsyg.2013.00424

Freeman, D., \& Freeman, J. (2008). Paranoia: The twenty-first century fear. Oxford: Oxford University Press.

Gauch, H. G. (2012). Scientific method in brief. In Scientific method in brief. Cambridge. https:// doi.org/10.1016/i.inoche.2016.06.032

Genovese, J. E. C. (2005). Paranormal beliefs, schizotypy, and thinking styles among teachers and future teachers. Personality and Individual Differences, 39(1), 93-102. https://doi. org/10.1016/i.paid.2004.12.008

Gervais, W. M., \& Norenzayan, A. (2012). Analytic thinking promotes religious disbelief. Science, 336(6080), 493-496. https://doi.org/10.1126/ science.1215647

Goreis, A., \& Voracek, M. (2019). A systematic review and meta-analysis of psychological research on conspiracy beliefs: Field characteristics, measurement instruments, and associations with personality traits. Frontiers in Psychology, 10(205). https://doi.org/10.3389/ fpsyg. 2019.00205

Globsec, (2020). Voices of Central and Eastern Europe: Perceptions of democracy \& governance in $10 \mathrm{EU}$ countries, Retrieved from https://www. globsec.org/publications/voices-of-central-andeastern-europe 
Graeupner, D., \& Coman, A. (2017). The dark side of meaning-making: How social exclusion leads to superstitious thinking. Journal of Experimental Social Psychology, 69, 218-222. https://doi. org/10.1016/i.jesp.2016.10.003

Grzesiak-Feldman, M. (2013). The effect of high-anxiety situations on conspiracy thinking. Current Psychology, 32, 100-118. https://doi.org/10.1007/ s12144-013-9165-6

Hackney, C. H., \& Sanders, G. S. (2003). Religiousness and mental health: A meta-analysis of recent studies. Journal for the Scientific Study of Religion, 42, 43-55. https://doi.org/10.1111/1468-5906. t01-1-00160

Halama, P. (2019a). Psychologické súvislosti konšpiračných teórií [Psychological context of conspiracy beliefs], Československá Psychologie, 63(3), 312-324.

Halama, P. (2019b). Konštrukcia a psychometrické vlastnosti Škály Epistemologicky Nepodložených Presvedčení [Construction and psychometric properties of the Epistemologically Unfounded Beliefs Scale]. In Sociálne procesy a osobnost' 2018: Zborník príspevkov (pp. 124133), Košice: Spoločenskovedný ústav CSPV SAV.

Hayes, A. F. (2013). An introduction to mediation, moderation, and conditional process analysis: $A$ regression-based approach. New York, NY: Guilford Press.

Heretik, A. ml., Mihálová, P., \& Hajdúk, M. (2018). Poruchy osobnosti - kategoriálny vs. dimenzionálny model a čo ešte chýba. Kapitoly z psychopatológie 10: 17. Dobrotkov deň a 22. Guensbergerov deň.

Hergovich, A., Schott, R., \& Arendasy, M. (2005). Paranormal belief and religiosity. Journal of Parapsychology, 69(2), 293-303.

Hergovich, A., Schott, R., \& Arendasy, M. (2008). On the relationship between paranormal belief and schizotypy among adolescents. Personality and Individual Differences, 45(2), 119-125. https://doi.org/10.1016/i.paid.2008.03.005

Hinterbuchinger, B., Litvan, Z., Meyer, E. L., Friedrich, F., Kaltenboeck, A., Gruber, M., König, D., Sueßenbacher, S., \& Mossaheb, N. (2018). Psychotic-like experiences in esoterism: A twilight zone? Schizophrenia Research, 193, 240-243. https://doi.org/10.1016/i.schres.2017.08.009
Hodapp, B., \& Zwingmann, C. (2019). Religiosity/ spirituality and mental health: A meta-analysis of studies from the German-speaking area. Journal of Religion and Health, 58(6), 1970-1998. https://doi.org/10.1007/s10943-019-00759-0

Hooker, S. A., Masters, K. S., \& Carey, K. B. (2014). Multidimensional assessment of religiousness/ spirituality and health behaviors in college students. International Journal for the Psychology of Religion, 24(3), 228-240. https://doi.org/10. $1080 / 10508619.2013 .808870$

Huntley, C., \& Peeters, T. (2005). Paranormal beliefs, religious beliefs and personality correlates. Retrieved from http://www.ethesis.net/paranormal/paranormal contence.htm

Jasinskaja-Lahti, I., \& Jetten, J. (2019). Unpacking the relationship between religiosity and conspiracy beliefs in Australia. British Journal of Social Psychology, 58(4), 938-954. https://doi. org/10.1111/bjso.12314

Johnson, M. (2004). Is knowledge of science associated with higher skepticism of pseudoscientific claims? The American Biology Teacher, 66(8), 536-548. https://doi.org/10.1662/0002-7685

Jolley, D., \& Douglas, K. M. (2017). Prevention is better than cure: Addressing anti-vaccine conspiracy theories. Journal of Applied Social Psychology, 47(8), 459-469. https://doi.org/10.1111/ jasp. 12453

Jolley, D., Meleady, R., \& Douglas, K. M. (2019). Exposure to intergroup conspiracy theories promotes prejudice which spreads across groups. British Journal of Psychology, 111(1), 17-35. https://doi.org/10.1111/bjop.12385

Koenig, H. G. (2008). Concerns about measuring "spirituality" in research. Journal of Nervous and Mental Disease, 196(5), 349-355. https://doi. org/10.1097/NMD.0b013e31816ff796

Krueger, R. F., Derringer, J., Markon, K. E., Watson, D., \& Skodol, A. E. (2012). Initial construction of a maladaptive personality trait model and inventory for DSM-5. Psychological Medicine, 42(9), 1879. https://doi.org/10.1017/S0033291711002674

Kwapil, T. R., \& Barrantes-Vidal, N. (2015). Schizotypy: Looking back and moving forward. Schizophrenia Bulletin, 41(suppl_2), S366-S373. https://doi. org/10.1093/schbul/sbu186

Lantian, A., Muller, D., Nurra, C., \& Douglas, K. M. (2017). "I know things they don't know!" the 
role of need for uniqueness in belief in conspiracy theories. Social Psychology, 48(3), 160-173. https://doi.org/10.1027/1864-9335/a000306

Lindeman, M., \& Aarnio, K. (2006). Paranormal beliefs: Their dimensionality and correlates. European Journal of Personality, 20(7), 585-602. https://doi.org/10.1002/per.608

Lindeman, M., \& Aarnio, K. (2007). Superstitious, magical, and paranormal beliefs: An integrative model. Journal of Research in Personality, 41(4), 731-744. https://doi.org/10.1016/i. irp.2006.06.009

Lobato, E., Mendoza, J., Sims, V., \& Chin, M. (2014). Examining the relationship between conspiracy theories, paranormal beliefs, and pseudoscience acceptance among a university population. Applied Cognitive Psychology, 28(5), 617-625. https://doi.org/10.1002/acp.3042

Miller, L. J. (2012). The Oxford handbook of psychology and spirituality. New York: Oxford University press.

Mancosu, M., Vassallo, S., \& Vezzoni, C. (2017). Believing in conspiracy theories: Evidence from an exploratory analysis of Italian survey data. South European Society and Politics, 22(3), 327-344. https://doi.org/10.1080/13608746.2017.1359894

Muris, P., Merckelbach, H., \& Peeters, E. (2003). The links between the Adolescent Dissociative Experiences Scale (A-DES), fantasy proneness, and anxiety symptoms. Journal of Nervous and Mental Disease, 191(1), 18-24. https://doi. org/10.1097/00005053-200301000-00004

Newheiser, A. K., Farias, M., \& Tausch, N. (2011). The functional nature of conspiracy beliefs: Examining the underpinnings of belief in the Da Vinci Code conspiracy. Personality and Individual Differences, 51(8), 1007-1011. https://doi. org/10.1016/i.paid.2011.08.011

Park, C. L. (2013). Religion and meaning. In R. F. Paloutzian \& C. L. Park (Eds.), Handbook of the psychology of religion and spirituality (pp. 357378). New York: The Guilford Press.

Park, C. L. (2017). Religious cognitions and well-being: A meaning perspective. In The Happy Mind: Cognitive Contributions to Well-Being (pp. 443458). Springer International Publishing. https:// doi.org/10.1007/978-3-319-58763-9 24

Pennycook, G., Cheyne, J. A., Seli, P., Koehler, D. J., \& Fugelsang, J. A. (2012). Analytic cognitive style predicts religious and paranormal belief. Cognition, 123(3), 335-346. https://doi.org/10.1016/i. cognition.2012.03.003

Raab, M. H., Ortlieb, S. A., Auer, N., Guthmann, K., \& Carbon, C.-C. (2013). Thirty shades of truth: Conspiracy theories as stories of individuation, not of pathological delusion. Frontiers in Psychology, 4, 406. http://doi.org/10.3389/fpsyg.2013.00406

Rice, T. W. (2003). Believe it or not: Religious and other paranormal beliefs in the United States. Journal for the Scientific Study of Religion, 42(1), 95-106. https://doi.org/10.1111/14685906.00163

Rindermann, H., \& Neubauer, A. C. (2004). Processing speed, intelligence, creativity, and school performance: Testing of causal hypotheses using structural equation models. Intelligence, 32(6), 573-589. https://doi.org/10.1016/i.intell.2004.06.005

Shein, P. P., Li, Y. Y., \& Huang, T. C. (2014). Relationship between scientific knowledge and fortune-telling. Public Understanding of Science, 23(7), 780-769. https://doi.org/10.1177/0963662514522169

Ståhl, T., \& Van Prooijen, J. W. (2018). Epistemic rationality: Skepticism toward unfounded beliefs requires sufficient cognitive ability and motivation to be rational. Personality and Individual Differences, 122, 155-163. https://doi.org/ 10.1016/i.paid.2017.10.026

Storch, E. A., Roberti, J. W., Bravata, E., \& Storch, J. B. (2004). Psychometric Investigation of the Santa Clara Strength of Religious Faith Questionnaire - ShortForm. Pastoral Psychology, 52(6), 479-483. https:// doi.org/10.1023/B:PASP.0000031526.64795.41

Suzuki, T., Griffin, S. A., \& Samuel, D. B. (2017). Capturing the DSM-5 alternative personality disorder model traits in the five-factor model's nomological net. Journal of Personality, 85(2), 220-231. https://doi.org/10.1111/jopy.12235

Suzuki, T., Samuel, D. B., Pahlen, S., \& Krueger, R. F. (2015). DSM-5 alternative personality disorder model traits as maladaptive extreme variants of the five-factor model: An item-response theory analysis. Journal of Abnormal Psychology, 124(2), 343-354. https://doi.org/10.1037/ abn0000035

Swami, V., Chamorro-Premuzic, T., \& Furnham, A (2010). Unanswered questions: A preliminary investigation of personality and individual difference predictors of 9/11 conspiracist beliefs. 
Applied Cognitive Psychology, 24(6),749-761. https://doi.org/10.1002/acp.1583

Swami, V., Coles, R., Stieger, S., Pietschnig, J., Furnham, A., Rehim, S., \& Voracek, M. (2011). Conspiracist ideation in Britain and Austria: Evidence of a monological belief system and associations between individual psychological differences and real-world and fictitious conspiracy theories. British Journal of Psychology, 120, 443-463. https://doi. org/10.1111/i.2044-8295.2010.02004.x

Swami, V., \& Furnham, A. (2012). Examining conspiracist beliefs about the disappearance of Amelia Earhart. In Journal of General Psychology, 139(4), 244-259. https://doi.org/10.1080/0 0221309.2012.697932

Swami, V., \& Furnham, A. (2014). Political paranoia and conspiracy theories. In Power, Politics, and Paranoia: Why People are Suspicious of their Leaders, 218-236. https://doi.org/10.1017/CB09781139565417.016

Swami, V., Nader, I. W., Pietschnig, J., Stieger, S., Tran, U. S., \& Voracek, M. (2012). Personality and individual difference correlates of attitudes toward human rights and civil liberties. Personality and Individual Differences, 53(4), 443-447. https://doi.org/10.1016/i.paid.2012.04.015

Swami, V., Furnham, A., Smyth, N., Weis, L., Lay, A., \& Clow, A. (2016). Putting the stress on conspiracy theories: Examining associations between psychological stress, anxiety, and belief in conspiracy theories. Personality and Individual Differences, 99, 72-76. https://doi.org/10.1016/i. paid.2016.04.084

Swami, V., Weis, L., Lay, A., Barron, D., \& Furnham, A. (2016). Associations between belief in conspiracy theories and the maladaptive personality traits of the personality inventory for DSM5. Psychiatry Research, 236, 86-90. https://doi. org/10.1016/i.psychres.2015.12.027

Tabachnick, B. G., \& Fidell, L. S. (2007). Using multivariate statistics (Fifth Edition). Boston: Pearson.

Tsai, C. Y., Shein, P. P., Jack, B. M., Wu, K. C., Chou, C. Y., Wu, Y. Y., Liu, C. J., Chiu, H. L., Hung, J. F., Chao, D., \& Huang, T. C. (2012). Effects of exposure to pseudoscientific television programs upon Taiwanese citizens' pseudoscientific beliefs. International Journal of Science Education, Part B: Communication and Public Engagement, 2(2), 175-194. https://doi.org/10.1080/215484 $\underline{55.2011 .610132}$
Underwood, L. G. (2011). The Daily Spiritual Experience Scale: Overview and results. Religions, 2(1), 29-50. https://doi.org/10.3390/ rel2010029

Van Elk, M. (2015). Perceptual biases in relation to paranormal and conspiracy beliefs. PLOS ONE. 10(6): e0130422. https://doi.org/10.1371/journal.pone.0130422

van Prooijen, J. W. (2016). Sometimes inclusion breeds suspicion: Self-uncertainty and belongingness predict belief in conspiracy theories. European Journal of Social Psychology, 46(3), 267-279. https://doi.org/10.1002/ejsp.2157

van Prooijen, J. W. (2017). Why education predicts decreased belief in conspiracy theories. Applied Cognitive Psychology, 31(1), 50-58. https://doi. org/10.1002/acp.3301

van Prooijen, J. W. (2018). The psychology of conspiracy theories. Oxon: Routladge.

van Prooijen, J. W., \& Jostmann, N. B. (2013). Belief in conspiracy theories: The influence of uncertainty and perceived morality. European Journal of Social Psychology, 43, 109-115. https://doi.org/10.1002/ ejsp.1922

van Prooijen, J. W., Krouwel, A. P. M., \& Pollet, T. V. (2015). Political extremism predicts belief in conspiracy theories. Social Psychological and Personality Science, 6(5), 570-578. https://doi. org/10.1177/1948550614567356

van Prooijen, J. W., \& van Vugt, M. (2018). Conspiracy theories: Evolved functions and psychological mechanisms. Perspectives on Psychological Science, 13(6), 770-788. https://doi. org $/ 10.1177 / 1745691618774270$

Wain, O., \& Spinella, M. (2007). Executive functions in morality, religion, and paranormal beliefs. International Journal of Neuroscience, 117(1), 135-146. https://doi. org/10.1080/00207450500534068

Widiger, T. A., \& Crego, C. (2019). HiTOP thought disorder, DSM-5 psychoticism, and five factor model openness. Journal of Research in Personality, 80, 72-77. https://doi.org/10.1016/i. irp.2019.04.008

Wood, M. J., Douglas, K. M., \& Sutton, R. M. (2012). Dead and alive: Beliefs in contradictory conspiracy theories. Social Psychological and Personality Science, 3(6), 767-773. https://doi. org/10.1177/1948550611434786 